\title{
Wpływ fal elektromagnetycznych i ultradźwiękowych na redukcję tkanki ttuszczowej u kobiet w wieku 25-45 lat oceniany za pomocą impedancji bioelektrycznej*
}

\section{Influence of electromagnetic and ultrasonic waves on the reduction of fat in women aged 25-45 years evaluated by the bioelectrical impedance method}

\author{
Jolanta Wesołowska $\bowtie$ \\ Pomorski Uniwersytet Medyczny w Szczecinie, Zakład Dermatologii Estetycznej, al. Powstańców Wlkp. 72, 70-111 Szczecin \\ $\triangle$ jolanta.wesolowska@pum.edu.pl
}

\begin{abstract}
Introduction: Excess body fat is a serious health problem, but also a very important aesthetic defect. Cosmetology as a field of health sciences may assist in all activities aimed at improving health and quality of life.

The aim of the study was to assess abdominal fat reduction in women aged 25-45 years after the application of ultrasonic and electromagnetic waves with a frequency of $1 \mathrm{MHz}$.

Materials and methods: The study involved 60 healthy women aged 25-45 years with excessive adipose tissue within the abdominal wall, qualified for the study on the grounds of abdominal fat percentage above $29 \%$, determined by bioelectrical impedance.
\end{abstract}

Results: 30 days after the end of the series of 10 treatments, the mean percentage of abdominal fat was reduced by $1.7 \%$ in the $\mathrm{RF}$ group, by $2.2 \%$ in the RF/U group and only by $0.6 \%$ in the $\mathrm{U}$ group compared to the baseline value.

Conclusions: In the method based on the combination of both applied techniques, a reduction of abdominal fat immediately after the treatment, as well as at 30 days of follow-up, seems to further confirm its beneficial effect on the studied parameter.

Keywords: reduction of fat; radiofrequency waves; ultrasonic waves; bioelectrical impedance.

\begin{abstract}
ABSTRAKT
Wstęp: Nadmiernie rozwinięta tkanka tłuszczowa jest poważnym problemem zdrowotnym, ale również bardzo istotnym defektem estetycznym. Kosmetologia jako dziedzina nauk o zdrowiu może wspomagać wszelkie działania mające na celu poprawę stanu zdrowia i jakości życia.

Celem pracy była ocena redukcji tkanki tłuszczowej tułowia u kobiet w wieku 25-45 lat po zastosowaniu fal ultradźwiękowych (U) o częstotliwości $1 \mathrm{MHz}$ i fal elektromagnetycznych o częstotliwości $1 \mathrm{MHz}$.

Materiały i metody: Badaniem objęto 60 zdrowych kobiet w wieku 25-45 lat z nadmiernie rozwiniętą tkanką tłuszczową w obrębie powłok brzusznych, kwalifikowanych do badań na podstawie zawartości tkanki tłuszczowej powyżej 29\%, oznaczonej za pomocą impedancji bioelektrycznej.
\end{abstract}

Wyniki: Po upływie 30 dni od zakończenia serii 10 zabiegów w grupie RF (fale radiowe) obserwowano obniżenie zawartości tłuszczu o 1,7\% w odniesieniu do stanu przed rozpoczęciem badania, w grupie RF/U (łącznie fale radiowe i ultradźwiękowe) o 2,2\%, natomiast w grupie U wartość tego parametru obniżyła się tylko o 0,6\%.

Wnioski: Najkorzystniejsze oddziaływanie na redukcję zawartości tłuszczu tułowia wywarły zastosowane łącznie obydwa bodźce fizykalne (fale radiowe i ultradźwiękowe). Obniżenie zawartości tłuszczu obserwowano bezpośrednio po zakończeniu zabiegów, jak i po upływie kolejnych 30 dni.

Słowa kluczowe: redukcja tkanki tłuszczowej; fale radiowe; fale ultradźwiękowe; impedancja bioelektryczna.

\section{WSTĘP}

Poglądy dotyczące estetycznego wyglądu sylwetki ciała zmieniały się na przestrzeni wieków w zależności od szerokości geograficznej, mody, kultury i zwyczajów. Współczesna estetyka ciała powinna racjonalnie przekładać się na prawidłowy stan zdrowia. W pojęciu kosmetologii estetyczna sylwetka związana jest z prawidłowo umięśnionym ciałem, bez nadmiaru tkanki tłuszczowej. Niekontrolowany rozwój tkanki tłuszczowej prowadzi do rozwoju otyłości, stanu skutkującego zwiększeniem masy ciała znacznie powyżej wartości prawidłowej - określonej dla danego wieku, płci i rasy. Otyłość uznana jest za epidemię XXI w. Według definicji Światowej Organizacji Zdrowia jest stanem patologicznym odpowiedzialnym za wiele chorób i powikłań zdrowotnych zagrażających życiu. Z otyłością związane są przede wszystkim choroby układu krążenia (choroba

* Zwięzła wersja rozprawy doktorskiej przyjętej przez Radę Wydziału Nauk o Zdrowiu Pomorskiego Uniwersytetu Medycznego w Szczecinie. Promotor prof. dr hab. n. med. Stanisława Bielecka-Grzela. Oryginał obejmuje: 90 stron, 27 rycin, 24 tabele i 97 pozycji piśmiennictwa. 
niedokrwienna serca, nadciśnienie tętnicze krwi), cukrzyca typu 2, a także inne, np. choroba zwyrodnieniowa stawów, obturacyjna choroba oskrzelowo-płucna, kamica pęcherzyka żółciowego [1,2,3]. Walka z nadwagą i otyłością jest bardzo skomplikowana, a okresowe diety przeważnie nie odnoszą oczekiwanego efektu. Zwykle po zakończeniu stosowania takiej diety następuje ponowny, bardzo szybki przyrost masy ciała, tak zwany efekt jo-jo $[4,5,6]$.

Kosmetologia jako jedna z dziedzin nauk o zdrowiu może pełnić ważną rolę w zapobieganiu powstawania nadwagi i otyłości, jak również w opracowaniu optymalnych metod zachowawczych wspomagających leczenie. Zabiegi określane ogólnie jako kosmetyczne to nie tylko zabiegi pielęgnujące skórę poprzez aplikację różnych substancji aktywnych, ale także szeroko rozumiane zabiegi fizykalne z zastosowaniem np. fal ultradźwiękowych czy elektromagnetycznych $[7,8,9,10]$.

Urządzenia stosowane w zabiegach kosmetycznych wyposażone są w głowice emitujące fale ultradźwiękowe o częstotliwości $1 \mathrm{MHz}$ i 3 MHz oraz dopuszczalnym natężeniu $2 \mathrm{~W} / \mathrm{cm}^{2}$ [11]. Fale ultradźwiękowe wywierają działanie cieplne, mechaniczne i fizykochemiczne [12,13,14]. Energia mechaniczna pochłonięta przez tkanki zostaje przekształcona w ciepło, powodując zmiany w postaci poprawy mikrokrążenia, przyspieszenia przemiany materii, aktywacji reakcji enzymatycznych, zwiększenia elastyczności włókien kolagenowych oraz przepuszczalności błon komórkowych [15, 16, 17].

W kosmetologii fale ultradźwiękowe stosowane są m.in. podczas zabiegów modelowania sylwetki ciała i zmniejszenia zawartości tkanki tłuszczowej, tzw. nieinwazyjnej liposukcji [18, 19, 20, 21].

Fale elektromagnetyczne (radiowe) o częstotliwości $1 \mathrm{MHz}$ są częścią spektrum elektromagnetycznego w zakresie 3 kHz-300 GHz i nie mają właściwości jonizujących [7, 8, 10, 22]. Aparatura zbudowana jest z układu elektronicznego wyposażonego w dwie metalowe elektrody wytwarzające drgania elektromagnetyczne. Zmienne pole elektryczne wytworzone w obwodzie wpływa na przesuwanie w tkance ładunków elektrycznych zgodnie z kierunkiem zmian pola. Efektem przesunięcia ładunków jest wytworzenie ciepła endogennego. Tkanki ogrzewane są do temperatury $45-55^{\circ} \mathrm{C}$. Ciepło generowane przez fale elektromagnetyczne o częstotliwości radiowej w znacznym stopniu jest absorbowane m.in. przez podskórną tkankę tłuszczową, mięśnie, płyny ustrojowe i narządy miąższowe. Wytworzone ciepło powoduje rozszerzenie naczyń krwionośnych oraz poprawę metabolizmu tkankowego, a także wpływa na rozerwanie międzycząsteczkowych wiązań krzyżowych włókien kolagenowych, powodując ich obkurczenie. Fale mogą być generowane w sposób ciągły lub impulsowy. W terapii impulsowej uzyskuje się mniejszy efekt termiczny, ale głębszą penetrację. Natomiast fala elektromagnetyczna (radiowa) generowana w sposób ciągły stymuluje wzrost ciepła w tkance. W temperaturze do $60^{\circ} \mathrm{C}$ wewnątrz adipocytów może dochodzić do rozrywania wiązań pomiędzy szkieletem glicerolu a kwasami tłuszczowymi. Wzrost temperatury do poziomu $65^{\circ} \mathrm{C}$ wiąże się z uszkodzeniem błon komórkowych [23, 24, 25].
Metody wykorzystania pola elektromagnetycznego uzależnione są od zastosowanych w aparaturze elektrod. Metoda monopolarna polega na zastosowaniu dwóch elektrod. Elektroda czynna jest mniejsza od elektrody pełniącej rolę anteny odbiorczej zamykającej obwód, ponadto jest miejscem większego zagęszczenia ładunków i silniejszego efektu cieplnego. W metodzie bipolarnej w głowicy zabiegowej dwie jednakowe elektrody umieszczone są blisko siebie. W tym przypadku ciepło jest intensywniej generowane w tkankach, które znajdują się między elektrodami. Metoda unipolarna polega na zastosowaniu jednej elektrody, która pełni rolę anteny emitującej fale elektromagnetyczne w głąb tkanki. Dawkowanie natężenia fal elektromagnetycznych i technika zabiegów uzależnione są od wskazań terapeutycznych. W jednej serii można wykonać 12-15 zabiegów [10, 11]. Przy małych dawkach energii i krótkim czasie trwania, wynoszącym 2-5 min, zabiegi mogą być wykonywane codziennie. W przypadku gdy zabiegi trwają 10-20 min, wykonywane są 2-3 razy w tygodniu. Dawkę energii ustala się na podstawie intensywności odczuwania ciepła przez pacjenta.

Zawartość tkanki tłuszczowej w organizmie człowieka określa się różnymi metodami, obliczając wskaźnik masy ciała (body mass index-BMI), stosując metodę ważenia hydrostatycznego, za pomocą densytometrii i rezonansu magnetycznego czy metodą impedancji bioelektrycznej zastosowaną w badaniu własnym [26, 27, 28, 29].

Postanowiono sprawdzić, w jakim stopniu fale ultradźwiękowe niezogniskowane oraz fale radiowe wywierają wpływ na redukcję nadmiernie rozwiniętej tkanki tłuszczowej u kobiet.

Celem pracy była ocena redukcji tkanki tłuszczowej tułowia u kobiet w wieku 25-45 lat po zastosowaniu fal ultradźwiękowych o częstotliwości $1 \mathrm{MHz}$, fal elektromagnetycznych o częstotliwości $1 \mathrm{MHz}$ oraz skojarzonego działania fal elektromagnetycznych o częstotliwości $1 \mathrm{MHz}$ i fal ultradźwiękowych o częstotliwości $1 \mathrm{MHz}$. Porównano również wyniki wpływu oddzielnego oraz skojarzonego działania fal elektromagnetycznych o częstotliwości $1 \mathrm{MHz}$ i fal ultradźwiękowych o częstotliwości $1 \mathrm{MHz}$ na redukcję tkanki tłuszczowej tułowia uzyskaną po przeprowadzeniu 9 zabiegów. Dokonano oceny zawartości tkanki tłuszczowej tułowia po upływie $30 \mathrm{dni}$ od zakończenia serii zabiegów.

\section{MATERIAŁY I METODY}

Badania przeprowadzono w Zakładzie Dermatologii Estetycznej Pomorskiego Uniwersytetu Medycznego w Szczecinie (PUM) po uzyskaniu zgody Komisji Bioetycznej PUM - Uchwała nr KB-0012/91/11.

Badaniem objęto 60 zdrowych kobiet (na podstawie badania podmiotowego) w wieku 25-45 lat z nadmiernie rozwiniętą tkanką tłuszczową w obrębie powłok brzusznych pochodzących ze Szczecina i okolic. Po wykluczeniu przeciwwskazań kobiety kwalifikowano do badań na podstawie zawartości tłuszczu tułowia powyżej 29\% oznaczonej za pomocą impedancji bioelektrycznej. 
Kobiety podzielono losowo na 3 grupy po 20 osób. W poszczególnych grupach wykonywano zabiegi, w których stosowano różne metody fizykalne: fale ultradźwiękowe (grupa U), fale radiowe (grupa RF) lub łącznie fale radiowe i ultradźwiękowe (grupa RF/U).

U każdej kobiety przeprowadzono 10 zabiegów. Zabiegi były wykonywane co drugi dzień, 3 razy w tygodniu, za pomocą urządzenia wielofunkcyjnego (Professional Beauty Equpment produkcji HEBE, Wrocław). Przed przystąpieniem do pierwszego zabiegu i przed każdym kolejnym zabiegiem, a także po upływie 30 dni od zakończenia serii 10 zabiegów u wszystkich kobiet przeprowadzono następujące pomiary: obwód talii - pomiar laserowy, procentową zawartość tłuszczu tułowia i poziom tłuszczu wisceralnego (trzewnego), co oznaczono metodą impedancji bioelektrycznej - miernik impedancji z 4 elektrodami brzusznymi. Pomiary te zostały przeprowadzone za pomocą aparatu produkcji japońskiej (TANITA AB-140 ViScan). Ponadto dokonano pomiarów grubości fałdu skórnego powłok brzusznych (fałdomierz BASELINE Fabrication Enterprises Incorporated, New York), masy ciała (waga elektroniczna) oraz wzrostu. Wskaźnik masy ciała określono, obliczając iloraz masy ciała (w kilogramach) i kwadratu wzrostu wyrażonego w metrach.

Obliczenia wykonano, stosując program Statistica v 10.0 (Statsoft) i przyjmując 5\% prawdopodobieństwo błędu [30]. Do oceny istotności różnic między wartościami w trzech badanych grupach zastosowano test Kruskala-Wallisa, a do porównania dwóch grup test U Manna-Whitneya dla pomiarów niepowiązanych oraz test rangowanych znaków Wilcoxona w celu oceny skuteczności metody (porównanie wartości określonego parametru przed rozpoczęciem badania - badanie I, po wykonaniu 9 zabiegów - badanie X i po 30 dniach od zakończenia serii 10 zabiegów - badanie K, korzystając z programu Prostat v 5.5 Poly Software International Inc. Pearl River - USA).

\section{ANALIZA WYNIKÓW}

Średnie wartości parametrów antropometrycznych w poszczególnych grupach wynosiły: wiek 34,5 $\pm 4,5$ lat w grupie U, $35,5 \pm 6,5$ lat $w$ grupie RF i $37,5 \pm 7,0$ lat $w$ grupie RF/U, masa ciała w poszczególnych grupach odpowiednio 79,4 $\pm 12,5 \mathrm{~kg}$, $71,0 \pm 8,6 \mathrm{~kg}, 77,1 \pm 13,7 \mathrm{~kg}$, wzrost 1,67 $\pm 0,10 \mathrm{~m}, 1,68 \pm 0,10 \mathrm{~m}$, $1,67 \pm 0,10$ m oraz BMI $28,7 \pm 4,7,25,4 \pm 3,0,28,0 \pm 4,7$.

Nie stwierdzono istotnego wpływu zastosowanych zabiegów na zmniejszenie masy ciała u badanych kobiet. Nieznaczne

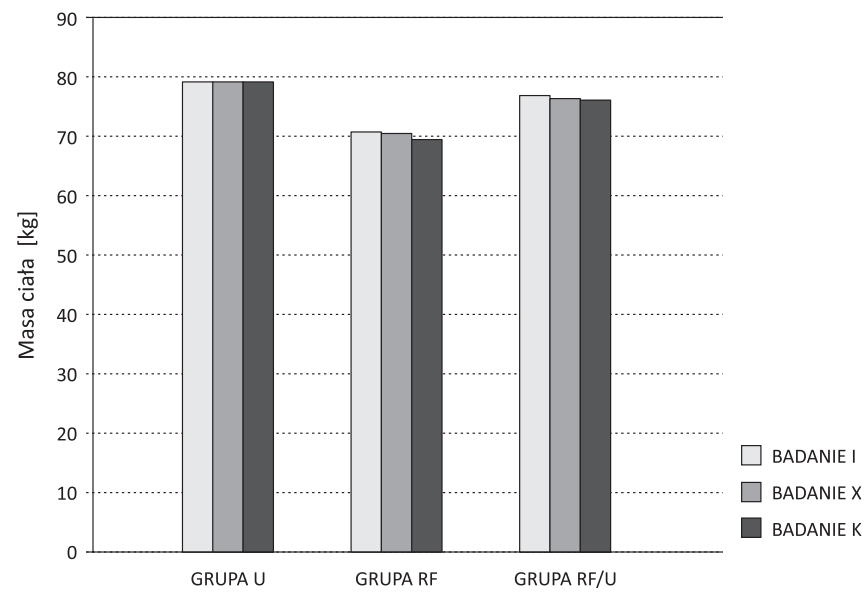

RYCINA 1. Porównanie wpływu przeprowadzonych zabiegów na masę ciała w badanych grupach kobiet

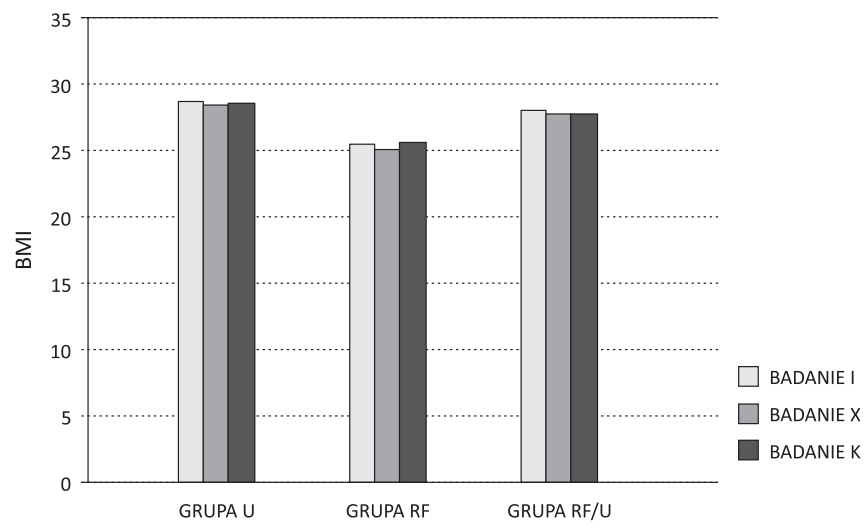

RYCINA 2. Porównanie wpływu przeprowadzonych zabiegów na wartość wskaźnika masy ciała (BMI) w badanych grupach kobiet

obniżenie masy ciała obserwowano podczas badania kontrolnego (po 30 dniach od zakończenia serii zabiegów) w grupie RF oraz w grupie RF/U, jednak wartości te również nie były istotne statystycznie (ryc. 1).

Nie stwierdzono także istotnego wpływu przeprowadzonych zabiegów na zmniejszenie wartości BMI w 3 badanych grupach kobiet (ryc. 2).

W tabeli 1 przedstawiono procentową zawartość tłuszczu tułowia w badanych grupach przed rozpoczęciem badań, w dniu wykonania ostatniego zabiegu oraz po 30 dniach od zakończenia serii 10 zabiegów.

W tabeli 2 przedstawiono procentową zawartość poziomu tłuszczu wisceralnego w grupach badanych: I, X oraz K.

TABELA 1. Procentowa zawartość tłuszczu tułowia (BIA\%)

\begin{tabular}{|c|c|c|c|c|c|c|}
\hline Badanie & & 20) & & 20) & & $=20)$ \\
\hline I & $\mathrm{X} \pm \mathrm{SD}$ & $42,0 \pm 5,4$ & $\mathrm{X} \pm \mathrm{SD}$ & $36,4 \pm 4,6$ & $\mathrm{X} \pm \mathrm{SD}$ & $41,8 \pm 5,4$ \\
\hline$X$ & $\mathrm{X} \pm \mathrm{SD}$ & $\begin{array}{c}41,5 \pm 5,6 \\
p=\mathbf{0 , 0 4 3 8}\end{array}$ & $X \pm S D$ & $\begin{array}{c}35,4 \pm 4,6 \\
p=0,0438\end{array}$ & $\mathrm{X} \pm \mathrm{SD}$ & $\begin{array}{c}40,6 \pm 5,9 \\
p=0,0002\end{array}$ \\
\hline $\mathrm{K}$ & $\mathrm{X} \pm \mathrm{SD}$ & $\begin{array}{c}41,4 \pm 5,8 \\
p=0,0671\end{array}$ & $X \pm S D$ & $\begin{array}{c}34,7 \pm 5,6 \\
p=0,0438\end{array}$ & $X \pm S D$ & $\begin{array}{c}39,6 \pm 5,6 \\
\mathbf{p}=\mathbf{0 , 0 0 0 1}\end{array}$ \\
\hline
\end{tabular}


TABELA 2. Poziom ttuszczu wisceralnego mierzonego w stopniach

\begin{tabular}{|c|c|c|c|c|c|c|}
\hline \multirow{2}{*}{$\frac{\text { Badanie }}{\text { I }}$} & \multicolumn{2}{|c|}{ Grupa $U(n=20)$} & \multicolumn{2}{|c|}{ Grupa RF (n = 20) } & \multicolumn{2}{|c|}{ Grupa RF/U (n = 20) } \\
\hline & $\mathrm{X} \pm \mathrm{SD}$ & $10,4 \pm 2,9$ & $\mathrm{X} \pm \mathrm{SD}$ & $7,4 \pm 1,9$ & $\mathrm{X} \pm \mathrm{SD}$ & $9,9 \pm 3,0$ \\
\hline$x$ & $X \pm S D$ & $\begin{array}{c}9,7 \pm 2,8 \\
\mathbf{p}=\mathbf{0 , 0 0 4 3}\end{array}$ & $\mathrm{X} \pm \mathrm{SD}$ & $\begin{array}{c}7,0 \pm 1,9 \\
\mathbf{p}=\mathbf{0}, 0376\end{array}$ & $X \pm S D$ & $\begin{array}{c}9,4 \pm 3,0 \\
p=0,0022\end{array}$ \\
\hline $\mathrm{K}$ & $\mathrm{X} \pm \mathrm{SD}$ & $\begin{array}{c}9,8 \pm 3,1 \\
p=0,0231\end{array}$ & $\mathrm{X} \pm \mathrm{SD}$ & $\begin{array}{c}6,8 \pm 2,0 \\
\mathbf{p}=\mathbf{0}, \mathbf{0 0 2 3}\end{array}$ & $\mathrm{X} \pm \mathrm{SD}$ & $\begin{array}{c}9,1 \pm 3,0 \\
\mathbf{p}=\mathbf{0}, 0001\end{array}$ \\
\hline
\end{tabular}

TABELA 3. Obwód talii mierzony w centymetrach

\begin{tabular}{|c|c|c|c|c|c|c|}
\hline Badanie & \multicolumn{2}{|c|}{ Grupa U (n = 20) } & \multicolumn{2}{|c|}{ Grupa RF $(n=20)$} & \multicolumn{2}{|c|}{ Grupa RF/U (n = 20) } \\
\hline I & $X \pm S D$ & $102,4 \pm 11,3$ & $\mathrm{X} \pm \mathrm{SD}$ & $92,3 \pm 7,7$ & $\mathrm{X} \pm \mathrm{SD}$ & $99,3 \pm 10,0$ \\
\hline$x$ & $X \pm S D$ & $\begin{array}{c}100,7 \pm 11,6 \\
p=0,0060\end{array}$ & $\mathrm{X} \pm \mathrm{SD}$ & $\begin{array}{c}90,5 \pm 7,0 \\
p=\mathbf{0 , 0 0 7 7}\end{array}$ & $X \pm S D$ & $\begin{array}{l}97,5 \pm 10,9 \\
\mathbf{p}=\mathbf{0 , 0 0 1 5}\end{array}$ \\
\hline K & $\mathrm{X} \pm \mathrm{SD}$ & $\begin{array}{c}100,6 \pm 12,5 \\
p=0,0231\end{array}$ & $\mathrm{X} \pm \mathrm{SD}$ & $\begin{array}{c}90,2 \pm 7,8 \\
\mathbf{p}=\mathbf{0}, \mathbf{0 0 1 4}\end{array}$ & $\mathrm{X} \pm \mathrm{SD}$ & $\begin{array}{l}95,6 \pm 10,0 \\
p=0,0007\end{array}$ \\
\hline
\end{tabular}

TABELA 4. Grubość fałdu brzusznego mierzona w milimetrach

\begin{tabular}{|c|c|c|c|c|c|c|}
\hline \multirow{2}{*}{ Badanie } & \multicolumn{2}{|c|}{ Grupa U (n = 20) } & \multicolumn{2}{|c|}{ Grupa RF (n = 20) } & \multicolumn{2}{|c|}{ Grupa RF/U (n = 20) } \\
\hline & $\mathrm{X} \pm \mathrm{SD}$ & $18,4 \pm 4,5$ & $\mathrm{X} \pm \mathrm{SD}$ & $15,1 \pm 3,5$ & $\mathrm{X} \pm \mathrm{SD}$ & $20,9 \pm 4,5$ \\
\hline$X$ & $\mathrm{X} \pm \mathrm{SD}$ & $\begin{array}{c}16,4 \pm 4,5 \\
p=0,0005\end{array}$ & $\mathrm{X} \pm \mathrm{SD}$ & $\begin{array}{c}13,2 \pm 4,0 \\
p=\mathbf{0 , 0 0 0 4}\end{array}$ & $\mathrm{X} \pm \mathrm{SD}$ & $\begin{array}{c}18,4 \pm 4,1 \\
p=0,0004\end{array}$ \\
\hline $\mathrm{K}$ & $\mathrm{X} \pm \mathrm{SD}$ & $\begin{array}{c}16,7 \pm 5,3 \\
p=0,0054\end{array}$ & $\mathrm{X} \pm \mathrm{SD}$ & $\begin{array}{c}12,7 \pm 4,8 \\
\mathbf{p}=\mathbf{0}, \mathbf{0 0 1 5}\end{array}$ & $\mathrm{X} \pm \mathrm{SD}$ & $\begin{array}{c}17,3 \pm 3,7 \\
\mathbf{p}=\mathbf{0}, 0002\end{array}$ \\
\hline
\end{tabular}

W tabeli 3 przedstawiono obwód talii w badanych grupach przed rozpoczęciem badań, w dniu wykonania ostatniego zabiegu oraz po 30 dniach od zakończenia serii 10 zabiegów.

W tabeli 4 przedstawiono grubość fałdu brzusznego w grupach badanych: I, X oraz K.

\section{DYSKUSJA}

Analiza statystyczna wyników uzyskanych w badaniu własnym nie wykazała istotnego wpływu zastosowanych metod na zmniejszenie masy ciała (M) i BMI, natomiast w wartościach pozostałych parametrów (procentowa zawartość tłuszczu tułowia, poziom tłuszczu wisceralnego, grubość fałdu skórnego powłok brzusznych, obwód talii) obserwowano zmiany.

Średnia procentowa zawartość tłuszczu tułowia między badaniem I (wyjściowym) i badaniem X (w dniu wykonania 10 zabiegu) obniżyła się we wszystkich grupach. W grupie U zmniejszyła się o 0,5\%, w grupie RF o 1,0\%, a w grupie RF/U o 1,2\%. W badaniu kontrolnym, przeprowadzonym po upływie 30 dni od zakończenia serii 10 zabiegów, w grupie RF obserwowano obniżenie średniej zawartości tłuszczu tułowia o $1,7 \%$ w odniesieniu do badania I, w grupie RF/U o 2,2\%, a w grupie U o 0,6\%. Należy podkreślić, że w dniu wykonania ostatniego zabiegu, jak również po 30 dniach od zakończenia serii 10 zabiegów największe obniżenie procentowej zawartości tłuszczu tułowia obserwowano w wyniku łącznego działania fal radiowych i ultradźwiękowych.

W przypadku poziomu tłuszczu wisceralnego również we wszystkich grupach stwierdzono zmniejszenie wartości tego parametru w badaniu X w odniesieniu do badania I. W grupie U poziom tłuszczu wisceralnego zmniejszył się średnio o 0,7 stopnia, w grupie RF o 0,4 stopnia, a w grupie RF/U o 0,5 stopnia. W badaniu K w odniesieniu do badania I poziom tłuszczu wisceralnego w grupie U obniżył się średnio o 0,6 stopnia, w grupie RF o 0,62 stopnia, a w grupie $\mathrm{RF} / \mathrm{U}$ o 0,8 stopnia.

Największy wpływ na ten parametr, po 9 przeprowadzonych zabiegach (badanie X), wywarło działanie fal ultradźwiękowych (grupa U). Natomiast po 30 dniach od zakończenia serii 10 zabiegów najkorzystniejszy efekt obniżenia poziomu tłuszczu wisceralnego w odniesieniu do badania I stwierdzono po zastosowaniu łącznie fal radiowych i ultradźwiękowych (grupa RF/U)

We wszystkich grupach obserwowano również zmiany zmniejszenia obwodu talii w badaniu X. W grupie U średnio o 1,7 cm, w grupie RF o 1,8 cm i w grupie RF/U także o 1,8 cm. $\mathrm{W}$ badaniu kontrolnym stwierdzono znaczne zmniejszenie w grupie RF/U w odniesieniu do wyniku badania I - średnio o 3,7 cm, w grupie RF o $2 \mathrm{~cm}$, a w grupie $U$ o 1,8 cm.

Uzyskane wyniki wskazują, że podczas badania X średnie zmniejszenie obwodu talii było porównywalne we wszystkich grupach kobiet, a po 30 dniach od zakończenia serii 10 zabiegów najkorzystniejsze oddziaływanie na ten parametr obserwowano w wyniku łącznego zastosowania fal radiowych i ultradźwiękowych.

Biorąc pod uwagę kolejny parametr - grubość fałdu skórnego powłok brzusznych, stwierdzono, że jego średnia wartość w badaniu X uległa zmniejszeniu w grupie U o $2 \mathrm{~mm}$, w grupie RF o 1,9 mm, a w grupie RF/U o 2,4 mm. Obserwowano również różnice wartości tego parametru między badaniem I oraz badaniem kontrolnym; mianowicie: w grupie U wartość 
ta zmniejszyła się średnio o 1,7 mm, w grupie RF o 2,4 mm, a w grupie RF/U o 3,6 mm.

Największy wpływ na zmniejszenie grubości fałdu skórnego powłok brzusznych, zarówno po 9 wykonanych zabiegach, jak i po 30 dniach od zakończenia serii 10 zabiegów, wywarły stosowane łącznie fale radiowe i ultradźwiękowe. Należy podkreślić, że po badaniu X największy wpływ na obniżenie procentowej zawartości tkanki tłuszczowej tułowia i na zmniejszenie grubości fałdu skórnego powłok brzusznych wywarły zastosowane łącznie fale radiowe i ultradźwiękowe.

Analiza wyników badań przeprowadzonych po 30 dniach od zakończenia serii zabiegów wskazuje, iż najkorzystniejszy wpływ, nie tylko na dalsze obniżenie procentowej zawartości tłuszczu tułowia i zmniejszenie grubości fałdu skórnego powłok brzusznych, ale także na zmniejszenie obwodu talii i obniżenie poziomu tłuszczu wisceralnego wywierały również stosowane łącznie fale elektromagnetyczne (radiowe) i fale ultradźwiękowe.

Na uwagę zasługuje obserwacja, iż po upływie $30 \mathrm{dni}$ od zakończenia serii zabiegów u niektórych kobiet nie tyko utrzymywały się wartości parametrów stwierdzone po badaniu X, ale także nastąpiła dalsza ich redukcja. Należy jednak podkreślić, że w każdej grupie występowały zarówno osoby, u których obserwowano znaczne obniżenie wartości badanych parametrów, jak i osoby, u których wartości tych parametrów uległy zwiększeniu.

Można przedstawić przykłady kobiet w poszczególnych grupach, u których stwierdzono zmniejszenie procentowej zawartości tłuszczu tułowia i obwodu talii zarówno po przeprowadzeniu 9 zabiegów, jak i po dalszych 30 dniach. W przypadku jednej z badanych kobiet w grupie U, po badaniu X zawartość tłuszczu tułowia obniżyła się o 0,8\%, obwód talii zmniejszył się $01 \mathrm{~cm}$. W badaniu K stwierdzono odpowiednio obniżenie o dalsze 2,9\% i zmniejszenie o kolejne $6 \mathrm{~cm}$. Z kolei w grupie RF u jednej z osób podczas badania X zawartość tłuszczu tułowia obniżyła się o 2,5\%, a obwód talii zmniejszył o $1 \mathrm{~cm}$. Po 30 dniach od zakończenia serii 10 zabiegów wartości tych parametrów uległy dalszemu znacznemu obniżeniu; odpowiednio o kolejne 4,3\% i o dalsze $2 \mathrm{~cm}$. W grupie RF/U wartości ocenianych parametrów u jednej z badanych po wykonaniu 9 zabiegów uległy znacznemu zmniejszeniu. Zawartość tłuszczu tułowia obniżyła się o 2,3\%, a obwód talii zmniejszył o $6 \mathrm{~cm}$. Podczas badania kontrolnego obserwowano dalsze obniżenie wartości badanych parametrów; odpowiednio o kolejne 2,6\% oraz o dalsze $6 \mathrm{~cm}$. Zatem w odniesieniu do wartości stwierdzonych podczas badania I obwód talii po 30 dniach od zakończenia serii 10 zabiegów zmniejszył się o $12 \mathrm{~cm}$, a zawartość tłuszczu tułowia obniżyła się o ok. 5\%.

Na podstawie przedstawionych wyników badań u kobiet z poszczególnych grup można stwierdzić korzystny wpływ przeprowadzonych zabiegów na wartości ocenianych parametrów zarówno po 9 wykonanych zabiegach, jak i po upływie 30 dni od zakończenia serii 10 zabiegów. U tych kobiet obniżenie wartości ocenianych parametrów po 9 zabiegach mogło wpływać mobilizująco na utrzymanie uzyskanego efektu, co znalazło odzwierciedlenie w dalszej redukcji procentowej zawartości tłuszczu tułowia i zmniejszeniu obwodu talii stwierdzonych po 30 dniach od zakończenia serii 10 zabiegów.

Odnotowano także przykłady braku poprawy wartości badanych parametrów u niektórych kobiet z poszczególnych grup po przeprowadzeniu 9 zabiegów. W grupie U u jednej z kobiet zawartość tłuszczu tułowia zmniejszyła się o 0,7\%, a obwód talii pozostał bez zmian. Natomiast podczas badania kontrolnego parametry te uległy zwiększeniu odpowiednio o $0,9 \%$ i o $2 \mathrm{~cm}$ (w odniesieniu do badania X). W grupie RF u jednej z osób zawartość tłuszczu tułowia obniżyła się o 0,8\%, a obwód talii zmniejszył o $4 \mathrm{~cm}$. W badaniu kontrolnym obserwowano wzrost obu parametrów odpowiednio o 0,8\% i o $3 \mathrm{~cm}$ (w odniesieniu do badania X). W grupie RF/U u jednej z badanych stwierdzono obniżenie procentowej zawartości tłuszczu tułowia o 1,1\% i zmniejszenie obwodu talii o $2 \mathrm{~cm}$. Jednakże po 30 dniach od zakończenia serii 10 zabiegów nastąpił wzrost odpowiednio o 0,6\% oraz o $1 \mathrm{~cm}$ (w odniesieniu do badania X).

Przedstawione powyżej wyniki pozwalają przypuszczać, że u tych kobiet korzystny efekt uzyskany po przeprowadzeniu 9 zabiegów mógł utwierdzić je w przekonaniu, iż będzie on długotrwały, a także pozwoli na większą liberalizację diety, co potwierdziły niektóre z badanych kobiet. Mogło to mieć wpływ na wzrost wartości ocenianych parametrów stwierdzonych podczas badania kontrolnego przeprowadzonego po upływie 30 dni od zakończenia serii 10 zabiegów.

Na podstawie przedstawionych przykładów oraz wyników uzyskanych w poszczególnych grupach kobiet można przypuszczać, że styl życia kobiet uczestniczących w badaniu nie pozostawał bez wpływu na wartości badanych parametrów. Ważne znaczenie wydaje się mieć również aspekt psychologiczny, co podkreślają także inni autorzy [31,32]. Innym czynnikiem, który mógł mieć wpływ na uzyskanie mniej lub bardziej korzystnych wyników, jest rodzaj zastosowanego w zabiegach bodźca fizykalnego. Metoda, w której stosowano oddzielnie fale ultradźwiękowe, w mniejszym stopniu wpłynęła na obniżenie wartości badanych parametrów w porównaniu z dwoma pozostałymi metodami. Może to być związane z zastosowaniem w badaniu własnym fal ultradźwiękowych niezogniskowanych o częstotliwości $1 \mathrm{MHz}$ i natężeniu 1,4 W/ $\mathrm{cm}^{2}$, które wykazują mniej intensywne działanie.

Fale ultradźwiękowe niezogniskowane o częstotliwości $1 \mathrm{MHz}$ są słabiej absorbowane przez tkankę tłuszczową, w związku z tym powodują mniejszy efekt termiczny i nie wywierają istotnego wpływu na skracanie włókien kolagenowych w odróżnieniu od fal ultradźwiękowych zogniskowanych o częstotliwości 1-10 MHz i większym natężeniu, które są silniej absorbowane przez tkankę tłuszczową i działają destrukcyjnie na komórki $[8,18,33,34]$. Fale ultradźwiękowe o częstotliwości $1 \mathrm{MHz}$ powodują drgania mechaniczne, wpływają na wzrost temperatury tkanek, oddziałują korzystnie na poprawę krążenia i metabolizm tkanki podskórnej, a także wywierają wpływ na wzrost przepuszczalności błon komórkowych adipocytów [35].

Według niektórych autorów zjawisko kawitacji powstaje w tkance tłuszczowej pod wpływem fal ultradźwiękowych o częstotliwości $1 \mathrm{MHz}$ i natężeniu $2 \mathrm{~W} / \mathrm{cm}^{2}$. Zjawisko kawitacji 
może również wystąpić przy wartościach natężenia tylko nieco wyższych od $1 \mathrm{~W} / \mathrm{cm}^{2}$, ale przy odpowiednio dłuższym czasie oddziaływania. W komórkach tłuszczowych pod wpływem działania fal ultradźwiękowych powstają pęcherzyki próżni zwiększające się do rozmiarów dziesiątych części milimetra, następnie dochodzi do tzw. implozji, czyli zapadania się pęcherzyków do środka. Powoduje to uszkodzenie komórki tłuszczowej i uwolnienie jej zawartości do przestrzeni pozakomórkowej [13, 17, 19, 20]. Przypuszcza się, że w ten sposób uwolnione triglicerydy są transportowane naczyniami układu limfatycznego do wątroby i ulegają dalszej przemianie [36, 37]

Można przyjąć, że fale ultradźwiękowe niezogniskowane zastosowane w badaniu własnym w mniejszym stopniu oddziaływały na proces kawitacji, co mogło mieć wpływ na niewielkie obniżenie wartości badanych parametrów.

Fale ultradźwiękowe są również stosowane w medycynie estetycznej, np. podczas zabiegów liposukcji ultradźwiękowej, lipolizy iniekcyjnej, jednak te zabiegi mogą być przeprowadzane przez lekarzy specjalistów [18, 37, 38].

Z kolei fale elektromagnetyczne (radiowe) o częstotliwości $1 \mathrm{MHz}$ i mocy $100 \mathrm{~W}$ (metoda bipolarna) zastosowane w badaniu własnym wykazywały korzystniejsze działanie na tkankę tłuszczową w porównaniu z działaniem fal ultradźwiękowych. W tkankach, na które oddziałuje pole elektromagnetyczne, wytwarzane jest ciepło endogenne. Pod wpływem miejscowego ogrzania skóry niektóre wiązania krzyżowe włókien kolagenowych ulegają rozerwaniu. Struktura potrójnej helisy włókien ulega rozwinięciu. Zachodzi częściowa denaturacja kolagenu, jednak bardziej termostabilne wiązania chemiczne zostają zachowane. Helisa włókien ulega rozluźnieniu, rozplata się i pogrubia. Włókna kolagenowe ulegają skróceniu, co klinicznie objawia się poprawą elastyczności skóry [14, 22, 24]. Częściowo zdenaturowany kolagen ulega naturalnej degradacji, co z kolei aktywuje fibroblasty do syntezy nowego kolagenu oraz zapoczątkowuje proces „remodelingu”, który może trwać od kilku tygodni do kilku miesięcy. Potwierdzają to wcześniejsze badania dotyczące dwuetapowego oddziaływania fal elektromagnetycznych na włókna kolagenowe [39]. Wytwarzane podczas zabiegu ciepło powoduje również poprawę metabolizmu tkankowego w miejscu wykonywania zabiegu, co wywiera wpływ na zmniejszenie zawartości tkanki tłuszczowej [19, 39, 40, 41].

Opisany proces mógł zaistnieć w wyniku przeprowadzonych w badaniu własnym zabiegów z zastosowaniem fal radiowych i przyczynić się do zmniejszenia wartości badanych parametrów, zwłaszcza po upływie 30 dni od zakończenia serii 10 zabiegów.

W badaniu własnym połączono również działanie obu rodzajów fal (radiowych i ultradźwiękowych). W pierwszej kolejności zastosowano masaż głowicą bipolarną generującą fale elektromagnetyczne (radiowe). Prawdopodobnie wytworzenie ciepła endogennego w tkance poddanej oddziaływaniu fal radiowych stworzyło optymalne warunki dla fal ultradźwiękowych poprzez wzmocnienie efektu ich działania, co mogło również mieć korzystniejszy wpływ na obniżenie wartości badanych parametrów w porównaniu z działaniem tylko jednego rodzaju fal. W przypadku tkanki tłuszczowej działanie fal radiowych powoduje termolipolizę; przyspieszeniu ulega metabolizm komórek tłuszczowych [21, 42]. Z kolei fale ultradźwiękowe wywierają wpływ na usprawnienie funkcji układu limfatycznego, co pośrednio wpływa na obniżenie zawartości tkanki tłuszczowej.

Podobne badania, dotyczące zmiany składu ciała pod wpływem działania fal radiowych (radio frequency) u młodych kobiet przeprowadzili Lewandowski i wsp. Analizę składu ciała ocenili metodą impedancji bioelektrycznej z elektrodami kończynowymi [40]. Autorzy badali wpływ 6 zabiegów z użyciem pola elektromagnetycznego na skład i masę ciała oraz na wybrane obwody kończyn dolnych u zdrowych kobiet w wieku 20-25 lat. Zabiegi były wykonywane metodą monopolarną, z pełnym wypełnieniem fali i o wyjściowym natężeniu $3 \mathrm{~W} / \mathrm{cm}^{2}$. Stwierdzono zmniejszenie masy tłuszczowej średnio o $0,6 \mathrm{~kg}$, co stanowiło $1 \%$ masy ciała. W badaniu własnym nie stwierdzono istotnego wpływu działania fal radiowych na masę ciała kobiet. Różnice te wynikają prawdopodobnie z zastosowania fal radiowych metodą monopolarną w odróżnieniu od metody bipolarnej stosowanej w badaniu własnym.

Levenberg opisał badania przeprowadzone u 37 pacjentek w wieku 23-82 lat, u których zastosował fale radiowe o częstotliwości $1 \mathrm{MHz}$ i maksymalnej mocy $50 \mathrm{~W}$ (głowice tripolarne o powierzchni 9,4 $\mathrm{cm}^{2}$ i 1,7 $\mathrm{cm}^{2}$ ) podczas zabiegów wykonywanych m.in. w okolicy twarzy i powłok brzusznych. U 16 pacjentek, u których zabiegi były przeprowadzone w obrębie powłok brzusznych, obwód talii zmniejszył się średnio o 4,5 cm (maksymalnie o 10,5 cm) [39]. W badaniu własnym, w grupie RF obwód talii zmniejszył się średnio o 2,4 cm (maksymalnie o $7 \mathrm{~cm}$ ). Różnice wartości tego parametru mogą wynikać m.in. z zastosowanej metody tripolarnej oraz liczby wykonanych zabiegów ustalanej indywidualnie w badaniu Levenberga [39].

Kaplan i Gat oceniali wpływ fal radiowych o częstotliwości $1 \mathrm{MHz}$ i maksymalnej mocy $30 \mathrm{~W}$ (metoda tripolarna, TriPollar $\mathrm{RF}$ ) na redukcję tłuszczu i regenerację włókien kolagenowych m.in. w okolicach powłok brzusznych, po wykonaniu 7 zabiegów w odstępach tygodniowych. W badaniu histopatologicznym tkanki podskórnej pobranej podczas chirurgicznej abdominoplastyki od jednej pacjentki stwierdzili komórki tłuszczowe o nieregularnych kształtach, niektóre z uszkodzoną błoną komórkową, natomiast grubość tej tkanki nie uległa zmianie [43]. W badaniu własnym określono wpływ fal radiowych na grubość fałdu skórnego powłok brzusznych, oceniając łącznie grubość skóry i tkanki podskórnej za pomocą fałdomierza. Średnia wartość tego parametru po upływie ok. 8 tygodni od wykonania pierwszego zabiegu obniżyła się o ok. 16\%. Średnią wartość tego parametru oceniono w oparciu o wyniki uzyskane u 19 badanych kobiet.

Na uwagę zasługuje badanie, które przeprowadziły Boisnic i Branchet. Autorki analizowały wpływ oddziaływania fal radiowych (metoda tripolarna) na lipolizę, stosując model skóry ludzkiej ex vivo. W tkance podskórnej obserwowały wzrost lipolizy (o ok. 120\%), co wiązało się z redukcją tłuszczu, a w badaniu histologicznym stwierdziły obecność komórek tłuszczowych o nieregularnych kształtach, z częściowo uszkodzoną błoną komórkową oraz zmiany martwicze na niewielkim 
obszarze [44]. Wyniki tych badań potwierdzają wpływ fal radiowych na tkankę tłuszczową.

Analiza wyników badań przeprowadzonych metodą impedancji bioelektrycznej (aparat Tanita AB-140 ViScan z 4 elektrodami brzusznymi) wskazuje na największą skuteczność zabiegów, w których zastosowano podwójną metodę (fale radiowe i fale ultradźwiękowe), mniejszą tych, w których wykorzystano działanie oddzielne fal radiowych, a najmniejszą tych, w której zastosowano tylko fale ultradźwiękowe.

Zastosowane w badaniu własnym nieinwazyjne metody fizykalne mogą być wykorzystane przede wszystkim w celu zapobiegania nadmiernemu rozwojowi tkanki tłuszczowej, a także jako wspomagające leczenie nadwagi i otyłości. Nie mogą one jednak stanowić podstawowego sposobu redukcji nadmiernie rozwiniętej tkanki tłuszczowej, niezależnie od jej lokalizacji. Ważne jest podkreślenie, że zastosowane w badaniu własnym łącznie fale radiowe i ultradźwiękowe oddziaływały na tkankę tłuszczową, co wpływało na częściową redukcję zawartości tłuszczu, a także na poprawę elastyczności skóry.

Należałoby również wspomnieć o możliwości połączenia działania tych fal z innymi metodami, co mogłoby wpłynąć na uzyskanie korzystniejszych wyników. Przykładem może być połączenie działania zarówno fal ultradźwiękowych, jak i radiowych z drenażem limfatycznym ręcznym lub próżniowym, laserem niskoenergetycznym biostymulacyjnym lub zabiegiem elektrostymulacji mięśni [45]. Należy podkreślić, że wszystkie wymienione zabiegi mogą być wykonywane przez kosmetologów. Ważnym zagadnieniem informacyjno-edukacyjnym, które powinno być uwzględnione w gabinetach kosmetycznych stosujących nieinwazyjne zabiegi fizykalne, jest uświadomienie osobom korzystającym z tych zabiegów, że w celu utrzymania uzyskanej redukcji tkanki tłuszczowej konieczna jest zmiana stylu życia obejmująca stosowanie odpowiedniej diety (bez okresów głodzenia) w połączeniu z optymalną aktywnością fizyczną. Ponadto osoby te powinny być poinformowane, że 1 czy 2 zabiegi nie będą mieć znaczącego wpływu na redukcję tkanki tłuszczowej. Wskazane również byłoby wyposażenie gabinetów kosmetologicznych wykonujących nieinwazyjne zabiegi redukcji tkanki tłuszczowej w niedrogą i łatwą w obsłudze aparaturę służącą do oceny parametrów określających nadwagę i otyłość, a także monitorującą na bieżąco efekty zabiegów.

Według Ostrowskiej i wsp. podstawowym celem leczenia otyłości jest redukcja masy ciała o 10\% w ciągu 12 miesięcy [46]. W realizacji tego celu miałyby zastosowane $\mathrm{w}$ badaniu własnym metody zabiegów, które mogłyby wchodzić w skład zarówno programów prewencyjnych, jak i leczniczych nadwagi oraz otyłości. W ten sposób kosmetologia jako dziedzina nauk o zdrowiu mogłaby współuczestniczyć w zapobieganiu rozwojowi chorób zagrażających życiu związanych z nadwagą i otyłością.

\section{WNIOSKI}

Wyniki przeprowadzonych badań pozwoliły wysunąć następujące wnioski:
1. Metoda, w której zastosowano fale ultradźwiękowe o częstotliwości $1 \mathrm{MHz}$, wydaje się mieć najmniejszy wpływ na redukcję zawartości tłuszczu tułowia.

2. Metoda, w której zastosowano fale radiowe o częstotliwości $1 \mathrm{MHz}$, wywarła korzystniejszy wpływ na obniżenie zawartości tłuszczu tułowia.

3. Najkorzystniejsze oddziaływanie na redukcję zawartości tłuszczu tułowia wywierały zastosowane łącznie obydwa bodźce fizykalne - fale radiowe i ultradźwiękowe.

4. W metodzie, w której połączono działanie obu rodzajów fal, stwierdzono obniżenie zawartości tłuszczu tułowia zarówno bezpośrednio po zakończeniu zabiegów, jak i po upływie kolejnych 30 dni, co może świadczyć o dalszym korzystnym wpływie na badany parametr.

Należałoby przeprowadzić podobne badanie z zastosowaniem (podczas jednostkowego zabiegu) połączonego oddziaływania fal ultradźwiękowych (z emisją fali ciągłej), fal elektromagnetycznych o wysokiej częstotliwości (z emisją fali ciągłej w metodzie monopolarnej) oraz elektrostymulacji w celu sprawdzenia, czy takie połączenie bodźców fizykalnych wpłynie na zmniejszenie zawartości tkanki tłuszczowej w obrębie powłok brzusznych, oceniając dodatkowo efekt zabiegów za pomocą obrazowania tkanki tłuszczowej Adipometrem.

\section{PIŚMIENNICTWO}

1. Bar-Andziak E. Otyłość i zespół metaboliczny a życie intymne i płodność. Przew Lek 2012;15:14-8.

2. Jarosz M, editor. Działania prowadzone w Polsce na rzecz zwalczania nadwagi i otyłości. Warszawa: II Zjazd Polskiego Towarzystwa Badań nad Otyłością; 2009, Oct. 15-17.

3. Musialik K. Wybrane wykładniki stanu zapalnego u pacjentów z zespołem metabolicznym. Przegl Kardiodiabetol 2012;7:29-35.

4. Tomiak E, Koziarska-Rościszewska M, Mizgała E, Mastalerz-Migas A, Broncel M, Olszanecka-Glinianowicz M. Zasady postepowania w nadwadze i otyłości w praktyce lekarza rodzinnego. Wytyczne Kolegium Lekarzy Rodzinnych w Polsce, Polskiego Towarzystwa Medycyny Rodzinnej, Polskiego Towarzystwa Badań nad Otyłością. 2014. ptmr.info.pl/wpcontent/uploads/2016/01/Otyłość-Rekomendacje.pdf (10.04.2016).

5. Cymeros M, Olek E. Ocena nawyków żywieniowych i stylu życia wśród chorych z otyłością brzuszną. Przegl Kardiodiabetol 2011;6:287-92.

6. Juruć A, Bogdański P. Osobowość w rozmiarze XXL. Psychologiczne czynniki ryzyka otyłości. Forum Zaburz Metabol 2011;2:34-42.

7. Jaroszyk F. Biofizyka. 2nd ed. Warszawa: Wyd. Lekarskie PZWL; 2008.

8. Moreno-Moraga J, Royo de la Torre J. Body contouring with focused ultrasound. In: Shiffman MA, Di Giuseppe A, editors. Body contouring. Berlin: Springer; 2010. p. 473-83.

9. Straburzyński G, Straburzyńska-Lupa A. Medycyna fizykalna. 3rd ed. Warszawa: Wyd. Lekarskie PZWL; 2003. p. 404.

10. Straburzyńska-Lupa A, Straburzyński G. Fizjoterapia. 3rd ed. Warszawa: Wyd. Lekarskie PZWL; 2003. p. 586-643.

11. Adamski Z, Kaszuba A, editors. Dermatologia dla kosmetologów. 1st ed. Poznań: Wyd. Naukowe UM; 2008. p. 323-5.

12. Ebelt-Paprotny G, Preis R. Fizjoterapia. Wrocław: Elsevier Urban \& Partner; 2012. p. 481-3.

13. Piwecki M. Fale radiowe. Cabines Polska 2011;46:4-9.

14. Paul M, Blugerman G, Kreindel M, Mulholland RS. Three-dimensional radiofrequency tissue tightening: a proposed mechanism and applications for body contouring. Aesthetic Plast Surg 2011;35:87-95.

15. Alam M, White LE, Martin N, Witherspoon J, Yoo S, West DP. Ultrasound tightening of facial and neck skin: a rater-blinded prospective cohort study. J Am Acad Dermatol 2010;62:262-9. 
16. Pisula-Lewandowska A. Dźwięk zamiast skalpela. Postępy Kosmetol 2011;4:290.

17. Piwecki M. Ultradźwięki i fala uderzeniowa. Cabines Polska 2011;47:8-11.

18. Hotta TA. Nonsurgical body contouring with focused ultrasound. Plast Surg Nurs 2010;30:77-82.

19. Piwecki M. Ultradźwięki w terapii i kosmetyce. Post Kosmetol 2011;1:51-2.

20. Szybiński S. Fale ultradźwiękowe w redukcji tkanki tłuszczowej - nowe polskie doniesienia o skuteczności. Med Contur Medical Dermatol Estet 2012;14:77.

21. Szwedo J, Sankowski A. Przegląd i podział urządzeń wykorzystujących energię RF (prądy wysokiej częstotliwości) w zabiegach nieinwazyjnych Dermatol Estet 2011;13:91-5.

22. Zarębska A, Szwedo J. Fale radiowe na pomoc piersiom. Med Estet Anti-Aging 2011;3:25-6.

23. Goursac C. Radiofrequence. AFME, Avril 2010:6-10.

24. Harth Y, Lischinsky D. A novel metod for real-time skin impedance measurement uring radiofrequency skin tightening treatments. J Cosmet Dermatol 2011;10:24-9.

25. Trelles MA, van der Lugt C, Mordon S, Ribe A, Al-Zaronni M. Histological findings in adipocytes when cellulite is treated with a variable-emission radiofrequency system. Lasers Med Sci 2010;25:191-5.

26. Cyganek K, Katra B, Sieradzki J. Porównanie pomiarów tkanki tłuszczowej u otyłych pacjentów z zastosowaniem metody bioimpedancji elektrycznej i densytometrycznej. Diabetol Prakt 2007;8:473-8.

27. Major-Gołuch A, Miazgowski T, Krzyżanowska-Świniarska B, Safranow K, Hajduk A. Porównanie pomiarów masy tłuszczu u młodych zdrowych kobiet z prawidłową masą ciała za pomocą impedancji bioelektrycznej i densytometrii. Endokrynol Otyłość 2010;6(4):189-95.

28. Socha M, Kamińska K, Chwałczyńska A. Porównanie zawartości tkanki tłuszczowej u młodych nieotyłych kobiet i mężczyzn oznaczonej metodą bioimpedancji (wersja Bi- i tetra polarna) i metodą fotooptyczną. Endokrynol Otyłość 2010;6:18-24.

29. Zamrazilowa H, Hlavaty P, Dusatkova L. A new simple method for estimating trunk and visceral fat by bioelectrical impedance: comparison with magnetic resonance imaging and dual X-ray absorptiometry in Czech adolescents. Cas Lek Cesk 2010:149:417-22.

30. Stanisz A. Przystępny kurs statystyki z zastosowaniem Statistica Pl na przykładach z medycyny. Statystyki podstawowe. Kraków: StatSoft Polska; 2000.

31. Brytek-Matera A. Obraz własnego ciała u otyłych kobiet: przyczyny i stopień niezadowolenia, związek z obniżoną samooceną i strategiami radzenia sobie ze stresem. Psychiatr Pol 2010;44:267-75.
32. Chanduszko-Salska J, Chodkiewicz J. Zadowolenie z życia a poczucie własnej skuteczności, wsparcie społeczne oraz stan zdrowia u kobiet z nadwagą i otyłością. Endokrynol Otyłość 2010;6:171-8.

33. Mekle H. Lipomioplastyka, czyli liporzeźbienie jako nowa jakość liposukcji. Dermatol Estet 2011;13:34-41.

34. Palumbo P, Cinque B, Miconi G, La Torre C, Zoccali G, Vrentozs N, et al. Biological effects of low frequency high intensity ultrasound application on ex vivo human adipose tissue. Int J Immunopathol Pharmacol 2011;24:411-22.

35. Osuch P. Zabiegi chirurgiczne na tkance tłuszczowej. In: Mamcarz B, Prandecka D, editors. Medycyna estetyczna w praktyce. 1st ed. Warszawa: Medica Education; 2010. p.121-31.

36. Gnacińska M, Małgorzewicz S, Guzek M. Adipose tissue activity in relation to overweight or obesity. Endokrynol Pol 2010;61:160-8.

37. Kępa A. Lipoliza iniekcyjno-kawitacyjna-nowatorskie podejście do kształtowania sylwetki. Derma News 2012;38:4-10.

38. Berry MG, Davies D. Liposuction: a review of principles and techniques. J Plast Reconstr Aesthet Surg 2011;64(8):985-92. doi: 10.1016/j.bjps. 2010.11.018.

39. Levenberg A. Clinical experience with a TriPollar radiofrequency system for facia and body aesthetic treatments. Eur J Dermatol 2010;20:615-9.

40. Lewandowski Z, Pisula-Lewandowska A, Turbiarz K, Socha M. Zmiany składu ciała pod wpływem zabiegów Radio Frequency (RF) u młodych kobiet. Dermatol Estet 2011;3(74):156-61.

41. Lowe ChE, O’Rahilly S, Rochford JJ. Adipogenesis at a glance. J Cell Sci 2011;124:2681-6.

42. Macierzyńska A, Pierzchała E. Wpływ fal elektromagnetycznych o wysokiej częstotliwości (RF) na poprawę elastyczności skóry. Dermatol Estet 2010;5(70):291-9.

43. Kaplan H, Gat A. Clinical and histopathological results following TriPollar radiofrequency skin treatments. J Cosmet Laser Ther 2009;11: 78-84.

44. Boisnic S, Branchet MC. Ex vivo human skin evaluation of localized fat reduction and anti-aging effect by TriPollar radio frequency treatments. J Cosmet Laser Ther 2010;12:25-31.

45. Maciuszek T. Wyjątkowe połączenie kawitacji ultradźwiękowej z falami radiowymi i masażem podciśnieniowym. Cabines Polska 2009;33:36.

46. Ostrowska L, Stefańska E, Adamska E, Tałałaj E, Waszczeniuk M. Wpływ leczenia dietą redukcyjną na skład ciała i modyfikację składników odżywczych w dziennej racji pokarmowej u otyłych kobiet. Endokrynol Otyłość 2010;6(4):179-88. 